\title{
Does Creative Thinking Infusion Learning Framework Enhance Students Entrepreneurial Skills?
}

Rifka Fachrunnisa ${ }^{1}$, Safitri Indah Putri Anisa ${ }^{1 *}$, Hadi Suwono ${ }^{1}$

${ }^{1}$ Biology Department, Universitas Negeri Malang, East Java

*corresponding author / email : safitri10indah@gmail.com

Artikel ini menyoroti strategi baru untuk menumbuhkan keterampilan kewirausahaan siswa dengan menerapkan pembelajaran infusi berpikir kreatif sebagai kerangka pembelajaran di kelas biologi. Pembelajaran infusi berpikir kreatif diartikan sebagai usaha membawa atau menunjukkan tahapan berpikir kreatif pemecahan masalah pemikiran siswa di dalam kelas. Untuk membantu siswa terlibat dengan infusi di kelas, kami menggunakan diagram berpikir kreatif untuk menghasilkan ide-ide kewirausahaan yang menerapkan konsep Biologi dalam memecahkan masalah. Keterampilan kewirausahaan siswa diukur dengan enam indikator kewirausahaan kreatif. Untuk mengetahui indikator-indikator tersebut, artikel ini menggunakan rancangan one group pre-test post-test design dan pendekatan metode campuran dengan menggunakan diagram thinking, angket, esai reflektif, dan wawancara. Hasil analisis tidak menunjukkan adanya pengaruh yang signifikan dari pembelajaran infusi berpikir kreatif terhadap keterampilan kewirausahaan. Hasil ini ditunjukkan dengan tidak terlihatnya perbedaan signifikansi pada keenam indikator.

\section{Kata Kunci : Berpikir kreatif; pembelajaran infuse; keterampilan berwirausaha}

This paper sheds a new light on the strategies to foster student's entrepreneurial skills by administering creative thinking infusion learning as the learning framework in a biology classroom. Creative thinking infusion learning is construed as bringing or showing the stages of creative problem solving's thinking of student thinking in the classroom. To assist student engaging with the infusion in the classroom, we utilised creative thinking diagram to generate entrepreneurial ideas that apply the concept of Biology in solving a problem. Student's entrepreneurial skills were gauged by six creative entrepreneurship indicators. To investigate those indicators, this paper administrated one group pre-test post-test design and mixed-method approach by using diagram thinking, questionnaires, reflective essays, and interview. The analysis did not show any significant impact of the creative thinking infusion learning towards entrepreneurial skills. This result was demonstrated by no significance differences were seen in the sixth indicators.

\section{Keywords : Creative Thinking; Infusion Learning; Entrepreneurial Skills}

Entrepreneurial skills are required to improve economic growth and development in modern society. It can be pursued by enhancing the quality of education, especially in problem-solving ideas that come from creative and innovative people. In general, students can learn creativity more professional from school and school also provides a great opportunity for established new entrepreneurship in the future. The essential roles of creative thinking skills is to solve a problem by finding unique ideas are to face the challenge of the creative industry in technology development and 
culture-changing that can impact business and consumption pattern (Im et al., 2015; Stamboulis \& Barlas, 2014). One of the successes to survive and evolve in the globalization era, which is dynamic and competitive, is to understand the role of the creative and innovative idea in entrepreneurship to get the benefit from gained knowledge and experience, so it can be a solution to cope with high unemployment especially in the confronting pandemic era (Iwu et al., 2019; Shalley et al., 2015). Interestingly, Biology and entrepreneurship have a mutual connection. For instance, the product innovations, which inspire entrepreneurs and scientists, come from nature. It immensely contribute to create solutions for human life, that so called biomimicry (Fernhaber \& Stark, 2019). Biology is a science subject that has an orientation to equip students to face the challenges of life in the 21st century. Creative thinking really needs to be integrated in every subject, including Biology (Zubaidah \& Corebima, 2018). In addition, in the most of cases, educators usually acknowledge the development of creativity implicitly by employing certain strategy, instead of teaching it explicitly step by step how to be creative. Educator also only give students instructions to create a creative and innovative idea to solve the problem in students' life cases, without facilitate them with the skills. In some counties, schools already dismissed the implementation of entrepreneurial skills in Biology subject due to it costed more budget and also it is time consuming. For this reason, there is an urgency to transform learning that only aims to understand concepts to apply concepts based on their function for life through the discovery of entrepreneurial ideas, so that the learning process will be more meaningful for student life and can provide them with career choices, particularly being entrepreneur.

Infusion thinking skill is a learning framework that can integrate thinking skills in the learning process such as creative thinking. Creative thinking infusion learning was employed in this research aims to clarifying or showing the stages of student thinking in solving a problem creatively. The benefit that we can get from this framework is to increase learners proficiency in science that connected into their life, thinking skills are easy to adapt in every topics and curriculum, reinforce content instruction that improves students comprehension, and develop thinking skills and the subject of the study at the same time (Lin, 2018; Zulkpli et al., 2017). Assuming this, this paper clarifies how to improve student's entrepreneurial skills in Biology subject by creative thinking infusion leaning framework. Through this framework as well, the author prospected the student in learning Biology can advance the nation's economy in the future.

\section{Creativity}

Creativity can emerge by involving discovery, originality, curiosity, imagination, experimentation, and exploration that leads to new and useful ideas. Creativity is also construed a process of solving problems combine with discovery in finding solutions or producing new things. The process of creativity also can be involving digital technology which then produces a transformation from what was known to something new that was previously unknown. During this creative thinking process, novelty reflects imagination, experience, and thinking abilities (Černochová \& Selcuk, 2019). There is a growing agreement that creativity is an important aspect of real-world intelligence that includes questioning assumptions, taking reasonable risks, and framing problems (Lucas, 2016). Creativity is often seen as synonymous with success. Some examples of the success enjoyed by creative people who have been achieved both in their personal and professional lives include the success of innovative institutions that are able to thrive in today's complex and dynamic work environment, the success of countries that foster healthy and invested creative industry sectors in research and development. This assumption is taken so broadly because creativity is usually defined, at least in psychology, as the process that leads to the generation of new or original and useful or effective products. These products do not have to be material, they can be ideas. The way to value students' creativity in the classroom is to describe a broader social discourse that considers students as active or passive agents in relation to their environment. This conception is shared by teachers or parents, and will be internalized by students and affect how and when they will act creatively, develop a creative identity, and self-efficacy or the belief that they can do something creatively (Glăveanu, 2018). 


\section{Entrepreneurial Skills}

Entrepreneurial skills are the ability to have self-confidence, courage, tenacity, empathy, and readiness to take advice from experts, desire to produce, visionary, and the ability to recognize opportunities (Shabbir et al., 2016). Interdisciplinary entrepreneurship education such as Biology is proven to be able to instil entrepreneurial skills and can introduce local entrepreneurship (Farber Canziani \& Welsh, 2019). Entrepreneurship education not only discusses concepts or ideas about business, marketing, and strategic planning, but entrepreneurship education can also improve entrepreneurial attitudes such as creative thinking, innovative thinking, risk-taking, motivation, and determination. Therefore to measure entrepreneurial knowledge should not only be based on the level of knowledge about business but also based on skills as a result of what students have learned (Damianus Abun et al., 2018).

\section{Creative Thinking Infusion Learning}

The infusion of elements of creativity into classrooms is an important movement in today's Asian educational reforms. A large-scale research was conducted in Hong Kong to explore the possibilities, outcomes and difficulties of such a curriculum change from a student perspective. This study developed a set of methods to instil elements of learning creativity into science lessons. After its implementation, students feel an increase in attitudes, conceptions, abilities, and behaviour in the development of creative science. Students characterize this creative thinking infusion learning as active and fun learning that motivates them to think broadly, appreciate creative ideas, develop curiosity, self-confidence, self-initiate in science learning, increase understanding, and illustrate the role of science in daily life (Cheng, 2011). Creativity requires a final product as a result, this product can be a useful new idea. Novelty is the main criterion for creativity that differentiates it from previous products. A creative product can be new if it is original, unusual, surprising and unexpectedly different. Novelty is not enough for creativity. Some extraordinary and unconventional novelties come from ideas that are unrealistic, wishful, or unattainable. New ideas of this kind are considered pseudocreative or quasi-creative and at worst eccentric and bizarre. Compared to novelty, usefulness is often seen as a secondary characteristic of creativity (Shalley et al., 2015).

\section{The Correlation}

Creativity is an important part of the characteristics of entrepreneurial behaviour. Idea is also an important part of entrepreneurship, which is then altered to be a novelty. Entrepreneurs must come up with an idea for a new product or service, and after identifying it, they have to find an effective way of doing this process because novelty and effectiveness are the hallmarks of a creative idea. Creativity also plays a role in shaping entrepreneurial intentions and having involvement in entrepreneurship education. It is important to know the difference in the potential for student creativity, because there is heterogeneity in the creative style among students. Students' creative styles play a role in entrepreneurship education that focuses on skills in teamwork, divergent thinking, and interpersonal communication. The integration of a creativity approach in entrepreneurship education can guide students to acquire new skills that are needed to interact with today's dynamic market. Creativity, innovation, and entrepreneurship are essential things that can create an entrepreneurial culture. The empirical findings show that most American and Spanish students who can see themselves as creative people think that creativity is related to innovation and entrepreneurship (Edwards-Schachter et al., 2015). There are four parallel key themes linking creativity, innovation and entrepreneurship. First, central to each of the three areas is the importance of new ideas. Second, the process of generating ideas is essential for every field. Third, involvement in being creative, innovative, or entrepreneurial. Finally, the overall context is also important for each area (Shalley et al., 2015). The analysis of the contribution of creativity to entrepreneurial theory and practice can be synthesized into a number of themes, ranging from consideration of definitions, its relationship to personality and cognitive style, creativity as a process and creative entrepreneurial behaviour. These factors are embedded in a critical evaluation of how creativity contributes to successful entrepreneurial practice (Fillis \& Rentschler, 2010). The research study design in this paper 
can be observed in Figure 1.

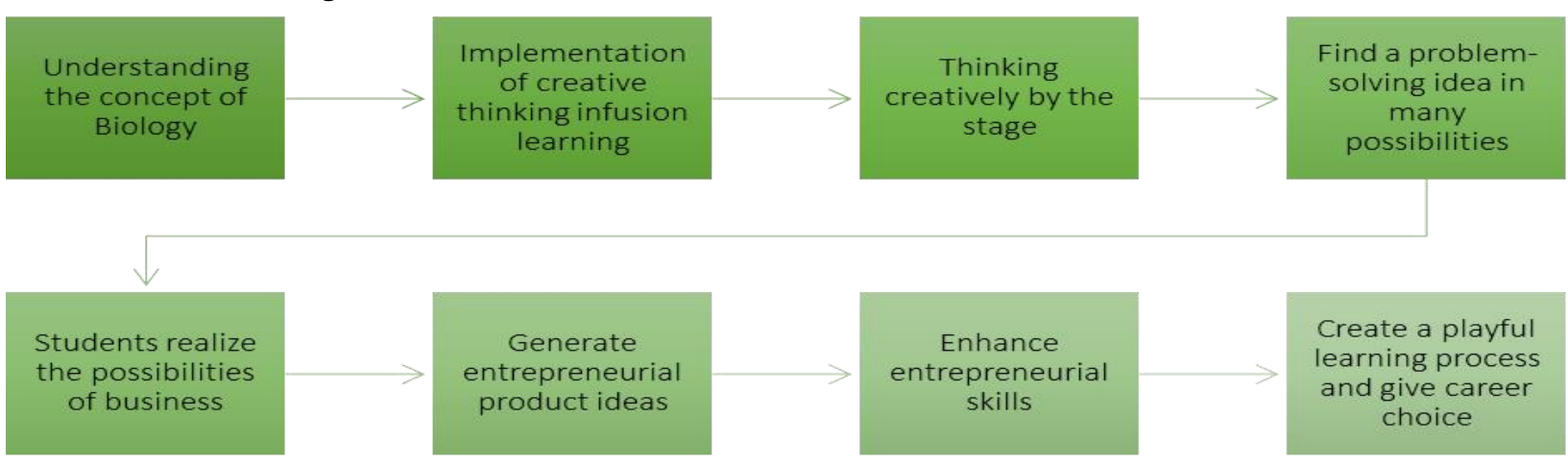

Figure 1. Research study design

\section{METHODS}

The research question in this paper is how's the effect of creative thinking infusion learning framework in Biology classroom on student's entrepreneurial skills. Participants in this research were students tenth grades from one of the government secondary school at Malang which consists of 33 students consisted 15 males and 18 females with the age ranges from 15 to 16 years old. The participants were picked by purposive sampling based on the cognitive level. Student's entrepreneurial skills were measured by technical skills in adaptability, listening skills, work organizing skills, and personal skills in inner-control, self-discipline, risk-taking (Fitriati \& Hermiati, 2010). This paper identified those indicators using diagram thinking based on creative thinking rubric, questionnaires, reflective essays, and semi-structured interviews with four students from low and high level cognitive in each level. The content validation about entrepreneurial skills and creativity concept was validated by experts in Biology education and psychometric. Internal consistency reliability was used to know the correlation between all items in entrepreneurial skills questionnaires measure the same concept (Md Ghazali, 2016). This paper was a pre-experimental research and administrated one group pre-test post-test design. Measurement was using a mixed-method approach that is concurrent nested (embedded) (Almeida, 2018). Educator's creativity was trained before creative thinking infusion learning is implemented in the class. Learner's ideas were accepted in every condition, which can be logic even if an imaginative idea to stimulate their confidence in argumentation the idea. Concept Biology that used in this paper is organism classification, especially on Kingdom Fungi, Plantae, and Animalia. The data are analyzed by using IBM SPSS 26 for quantitative data and NVivo 12 for qualitative data. The simple linear regression correlation was tested using to measure effect of Biology learning infusion of creative thinking on entrepreneurial skills which Kolmogorov-Smirnov normality test is used as a prerequisite test before it.

\section{RESULT AND DISCUSSION}

According to the diagram creative thinking and entrepreneurial skills questionnaires at the pretest and post-test the Kolmogorov-Smirnov normality test are Normal with a signification score of 0,200 which means the residual score is distributed normally.

The results of the paired $t$ test, it is known that the Sig. (2-tailed) of $0.589>0.05$, it can be concluded that there is no significant difference between the entrepreneurial skills data in the pretest and post-test data. This means that through creative thinking infusion learning framework cannot enhance student's entrepreneurial skills. The results of the paired t-test statistical analysis of the pretest and post-test scores of entrepreneurial skills can be seen in Table 1. 


\begin{tabular}{|c|c|c|c|c|c|c|c|c|}
\hline & \multirow[b]{2}{*}{ Mean } & \multirow{2}{*}{$\begin{array}{c}\text { Std. } \\
\text { Deviation }\end{array}$} & \multirow{2}{*}{$\begin{array}{l}\text { Std. Error } \\
\text { Mean }\end{array}$} & \multicolumn{2}{|c|}{$\begin{array}{l}\text { 95\% Confidence } \\
\text { Interval of the } \\
\text { Difference }\end{array}$} & \multirow[b]{2}{*}{$\mathrm{t}$} & \multirow[b]{2}{*}{$d f$} & \multirow[b]{2}{*}{ Sig. (2-tailed) } \\
\hline & & & & Lower & Upper & & & \\
\hline $\begin{array}{l}\text { Pretest \& Posttest } \\
\text { Entrepreneurial } \\
\text { Skills }\end{array}$ & $-0,47475$ & 4,99307 & 0,86918 & $-2,24521$ & 1,29572 & $-0,546$ & 32 & 0,589 \\
\hline
\end{tabular}

Table 2. Simple Linear Regression Correlation Test

Coefficients $^{\mathrm{a}}$

\begin{tabular}{|c|c|c|c|c|c|}
\hline \multirow[b]{2}{*}{ Model } & \multicolumn{2}{|c|}{ Unstandardized Coefficients } & \multirow{2}{*}{$\begin{array}{c}\text { Standardized } \\
\text { Coefficients } \\
\text { Beta }\end{array}$} & \multirow[b]{2}{*}{$\mathrm{t}$} & \multirow[b]{2}{*}{ Sig. } \\
\hline & B & Std. Error & & & \\
\hline (Constant) & 110,525 & 11,888 & & 9,297 & 0,000 \\
\hline Creativity & 0,577 & 0,971 & 0,106 & 0,594 & 0,557 \\
\hline
\end{tabular}

a. Dependent Variable: Entrepreneurial Skills

Table 2. equation can explain that a constant of 110.525 means that the consistent value of the entrepreneurial skills variable is 110.525 . The $X$ regression coefficient of 0.577 explains that every $1 \%$ increase in the value of creative thinking infusion, then the value of entrepreneurial skills increases by 0.577 . The regression coefficient is positive (positive number), it can be concluded that the direction of the influence of the creative thinking infusion variable on entrepreneurial skills is positive. Decision making simple regression test based on the significance value of the coefficient table obtained a significance value of $0.557>0.05$ so it can be concluded that the creative thinking infusion learning framework variable has no effect on student's entrepreneurial skills. Based on the $t$ value, it is known that the $t$ count value is $0.594<t$ table 2.040 so it can be concluded that the creative thinking infusion learning framework variable has no effect on the entrepreneurial skills variable. So that the hypothesis which says there is an effect of creative thinking infusion learning framework on student's entrepreneurial skills is rejected.

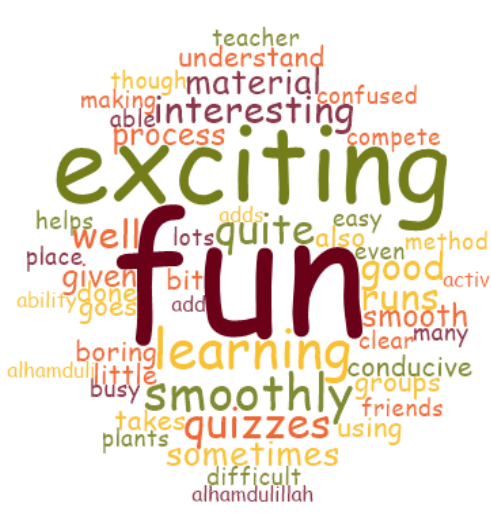

(a)

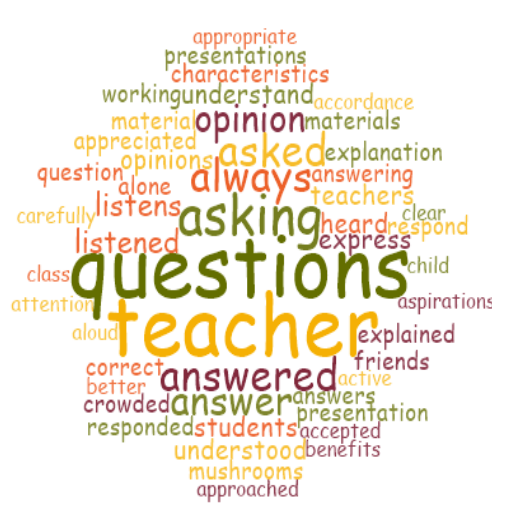

(b)

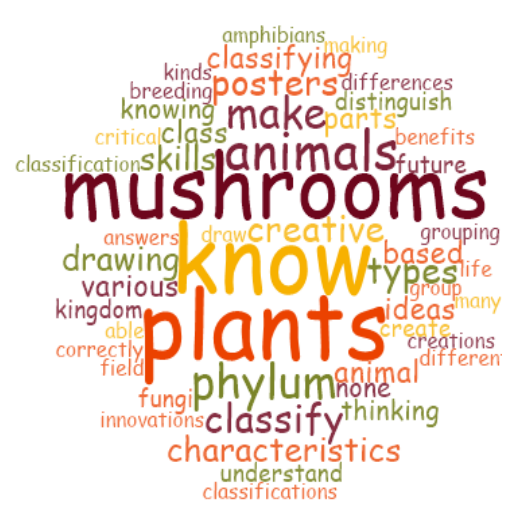

(c)

Figure 2. (a) Student's learning process, (b) Student's learning value, (c) Student's skills 
Fig. 2 point (a) and (b) is going to shows you the word cloud of the student's learning process and learning value based on reflective essays and point (c) is explained student's skills after creative thinking infusion learning.

Student's issues in generating a problem-solving idea in a creative way, which then can improve their entrepreneurial skills, were fostered by giving a thematic topic with divergent questions can stimulate creativity. This will happen only with the provision that the topic must be contextual with their life. The integration of creative thinking skills - which employed a creative thinking diagram showed the phase of creative thinking with indicators fluency, flexibility, originality, and elaborationgenerate students' entrepreneurial ideas by manipulating Biology concepts to solve a problem. The first step is to generate a bunch of ideas that are explained fluently in creativity. Secondly, is the classification of the idea by various conceptual which are describe student's flexibility. Next, find surprisingly and out of the box idea which includes originality. The last is elaborate, augment, and enhance the idea in various plans and concepts which are explained ability in elaboration (Gralewski, 2019).

Referring to the students 'opinions based on their reflective essays about their opinions before and after the infusion took place on Fig. 2 in accordance with Cheng's research results that after the teacher instilled the elements of learning creativity in Science, there was an increase in students' understanding, attitudes, abilities, and behaviour in the development of creative science. Most students felt some significant changes in learning in the classroom. They characterized this infusion of creative thinking as active and enjoyable learning, encouraging them to think more broadly, appreciate creative ideas, develop curiosity, self-confidence, promote a better understanding of science knowledge, and apply Science more to life. daily. Unfortunately, in this study students emphasized their learning more about the content of science subjects, not on creativity, and it happened too in this research. These tensions and dilemmas appear to stem from changes in learning styles, time constraints, knowledge-oriented examinations, and a lack of skill-specific tasks (Cheng, 2011). The advantages of this research than previous research was that students not just generate a problem-solving idea creatively but add sale value too by making a design poster and essay of their entrepreneurship product ideas.

The negative result of simple linear regression correlation test conveyed that creative thinking infusion learning in the Biology learning process could not improve student's entrepreneurial skills. In another way, student's interviews described it that their family background and individual factor have a big impact on their entrepreneurial skills indicators, especially in risk-taking in making a big decision like major that they choose at the campus in the future (Y. Wang \& Poutziouris, 2010). Other than that culture and communication which in this research are listening skills are can affect the production of innovative design ideas (Sidawi, 2016). The following is a snippet of the interview results.

Khd; Shdq; Almr; Zlf $\quad$ :I match my talents and interest

Khd; Zlf; Zlvd

ability to

Shdq; Pnkn

me to

Almr

but keep

Ilhm choice. My

Zlf; Zlvd

Evd know what
:I just ask for suggestions to my parents, because of their experience and understand me. Allah's pleasure depends on the parent's approval.

:I have my own decision, my parents never controlling me because they teach responsible

:Look at my abilities first, interest, and then continue to see the opportunities, asking for opinions from people closest to me and my parents

:Well prepared and then I asked my parents for suggestions about my second parents usually keep track of my achievement

:Looking for passion, and supported by prayer

:I'm looking for information and inspiration. My choice my decision because I I want and I am afraid that someone will deviate 
Previous research explained that entrepreneurship can be stimulated by family background, such as entrepreneurship cultures in Banjar ethnic family. Several researchers also assumed that culture can be influence creativity performance which in this study is applied to enhance entrepreneurial skills (Ranwala, 2016; Tri Harinie, 2019; A. Y. Wang, 2012). Our results confirmed that entrepreneurial skills are not just influenced by family background and individual factors but also ethnographic. For this reason, the author suggests other teachers or researchers give problems in creative thinking infusion learning contextual and adjust to student's culture. Previous studies suggested employing a ethnographic method to analysed student's entrepreneurial skills due to this method is flexible and has a firm instrument to evaluate entrepreneurship in education. Ethnography is a research method that seeks to gain a more detailed understanding of how participants perceive their surroundings and how they understand the problems they have to face in everyday life. This method is also ideal for studying practices carried out by educators that involve entrepreneurship in learning and changes in the ability to use reasoning and cognitive abilities experienced by students when they are looking for an understanding of entrepreneurship, especially in the field of Biology. This needs to be investigated further, because entrepreneurship has always had an important role in economic development and is increasingly playing an important role in many aspects of life in the 21st century. Evidenced by the creation of more entrepreneurs explicitly also encouraging human behaviour for entrepreneurship, therefore teaching entrepreneurship to students at all levels of education is important (Robinson \& Shumar, 2014).

It is hoped that this research can inspire educational anthropologists by exploring the parameters of this new discipline. Researchers propose that the nature of this creative thinking infusion framework on entrepreneurial skills is suitable to be discussed ethnographically as a method of discussion about how big the role of behaviour is fostered, supported, and developed into entrepreneurial practice through socially constructed communities. Cheng (2011) himself agrees that the results found in this infusion of creative thinking are related to several characteristics typical of Eastern culture and its education system. His research suggests that the infusion of creative thinking is likely to be limited by subject curricula, local education systems, and social culture. This provides additional support for the infusion characteristics of contextual and cultural-based creative thinking that exist in the student environment.

\section{CONCLUSION}

To sum up, our work confirmed that there is no effect of creative thinking infusion learning on entrepreneurial skills of tenth-grade students from one of the government secondary school at Malang. The author's suggestion for future studies is an implementation of creative thinking infusion learning on students' entrepreneurial skills requires further measurement, both regarding family background, individual factors, and even culture which can be viewed from an ethnographic point of view. Second, the topics that should be presented during the creative thinking infusion learning not only contextual to the student's life but also should follow the culture embedded in the student's learning environment. The author prospect the next learning can be analyzed individual culture and habit in the school environment which can influence the learning process.

\section{REFERENCES}

Almeida, F. (2018). Strategies To Perform A Mixed Methods Study. European Journal of Education Studies, 5(1), 1-16. https://doi.org/10.5281/zenodo.1406214

Černochová, M., \& Selcuk, H. (2019). Digital Literacy, Creativity, and Autonomous Learning. In A. Tatnall (Ed.), Encyclopedia of Education and Information Technologies (pp. 1-8). Springer International Publishing. https://doi.org/10.1007/978-3-319-60013-0_205-1

Cheng, V. M. Y. (2011). Infusing creativity into Eastern classrooms: Evaluations from student perspectives. Thinking Skills and Creativity, 6(1), 67-87. https://doi.org/10.1016/j.tsc.2010.05.001 
Damianus Abun, Lalaine, S., Luisita, M., V Belandres, Agoot, F., \& Theogenia Magallanez. (2018). Measuring Entrepreneurial Knowledge and Entrepreneurial Intention of ABM Grade XII, Senior High School Students of Divine Word Colleges in Region I, Philippines. https://doi.org/10.13140/RG.2.2.31410.66249

Edwards-Schachter, M., García-Granero, A., Sánchez-Barrioluengo, M., Quesada-Pineda, H., \& Amara, N. (2015). Disentangling competences: Interrelationships on creativity, innovation and entrepreneurship. Thinking Skills and Creativity, 16, 27-39.

https://doi.org/10.1016/j.tsc.2014.11.006

Farber Canziani, B., \& Welsh, D. H. B. (2019). How entrepreneurship influences other disciplines: An examination of learning goals. The International Journal of Management Education, S1472811718303112. https://doi.org/10.1016/j.ijme.2019.01.003

Fernhaber, S. A., \& Stark, A. Y. (2019). Biomimicry: New insights for entrepreneurship scholarship. Journal of Business Venturing Insights, 12, e00137. https://doi.org/10.1016/j.jbvi.2019.e00137

Fillis, I., \& Rentschler, R. (2010). The Role Of Creativity In Entrepreneurship. Journal of Enterprising Culture, 18(01), 49-81. https://doi.org/10.1142/S0218495810000501

Fitriati, R., \& Hermiati, T. (2010). Entrepreneurial Skills and Characteristics Analysis on the Graduates of the Department of Administrative Sciences, FISIP Universitas Indonesia. Journal of Administrative ScienceS \& Organization, 17(3), 262-275.

Glăveanu, V. P. (2018). Educating which creativity? Thinking Skills and Creativity, 27, 25-32. https://doi.org/10.1016/j.tsc.2017.11.006

Gralewski, J. (2019). Teachers' beliefs about creative students' characteristics: A qualitative study. Thinking Skills and Creativity, 31, 138-155. https://doi.org/10.1016/j.tsc.2018.11.008

Im, H., Hokanson, B., \& Johnson, K. K. P. (2015). Teaching Creative Thinking Skills: A Longitudinal Study. Clothing and Textiles Research Journal, 33(2), 129-142. https://doi.org/10.1177/0887302X15569010

Iwu, C. G., Opute, P. A., Nchu, R., Eresia-Eke, C., Tengeh, R. K., Jaiyeoba, O., \& Aliyu, O. A. (2019). Entrepreneurship education, curriculum and lecturer-competency as antecedents of student entrepreneurial intention. The International Journal of Management Education, S147281171830288X. https://doi.org/10.1016/j.ijme.2019.03.007

Lin, Y. (2018). The Infusion Approach. In Y. Lin, Developing Critical Thinking in EFL Classes (pp. 9-17). Springer Singapore. https://doi.org/10.1007/978-981-10-7784-5_2

Lucas, B. (2016). A Five-Dimensional Model of Creativity and its Assessment in Schools. Applied Measurement in Education, 29(4), 278-290. https://doi.org/10.1080/08957347.2016.1209206

Md Ghazali, N. H. (2016). A Reliability and Validity of an Instrument to Evaluate the School-Based Assessment System: A Pilot Study. International Journal of Evaluation and Research in Education (IJERE), 5(2), 148. https://doi.org/10.11591/ijere.v5i2.4533

Ranwala, R. S. (2016). Family Background, Entrepreneurship Specific Education and Entrepreneurial Knowledge in Venture Creation. International Journal of Scientific and Research Publications, 6(9), 495-501.

Robinson, S., \& Shumar, W. (2014). Ethnographic evaluation of entrepreneurship education in higher education; A methodological conceptualization. The International Journal of Management Education, 12(3), 422-432. https://doi.org/10.1016/j.ijme.2014.06.001

Shabbir, M. S., Shariff, M. N. M., \& Shahzad, A. (2016). Determinants of Entrepreneurial Skills set in Pakistan: A Pilot Study. International Journal of Academic Research in Accounting, Finance and Management Sciences, 6(2), Pages 76-86. https://doi.org/10.6007/IJARAFMS/v6-i2/2048

Shalley, C. E., Hitt, M. A., \& Zhou, J. (Eds.). (2015). The Oxford handbook of creativity, innovation, and entrepreneurship. Oxford University Press.

Sidawi, B. (2016). The role of healthy social interaction and communications in provoking creativity in the design studio. Higher Education Pedagogies, 1(1), 64-81.

https://doi.org/10.1080/23752696.2015.1134205

Stamboulis, Y., \& Barlas, A. (2014). Entrepreneurship education impact on student attitudes. The 
International Journal of Management Education, 12(3), 365-373.

https://doi.org/10.1016/j.ijme.2014.07.001

Tri Harinie, L. (2019). Ethnographic Study on Cultural Entrepreneurship of Banjar Ethnic Family in Indonesia. Social Sciences, 8(1), 22. https://doi.org/10.11648/j.ss.20190801.14

Wang, A. Y. (2012). Exploring the relationship of creative thinking to reading and writing. Thinking Skills and Creativity, 7(1), 38-47. https://doi.org/10.1016/j.tsc.2011.09.001

Wang, Y., \& Poutziouris, P. (2010). Entrepreneurial risk taking: Empirical evidence from UK family firms. International Journal of Entrepreneurial Behavior \& Research, 16(5), 370-388. https://doi.org/10.1108/13552551011071841

Zubaidah, S., \& Corebima, A. D. (2018). Pengaruh Gender terhadap Keterampilan Berpikir Kreatif Siswa pada Pembelajaran Biologi. Jurnal Pendidikan: Teori, Penelitian, dan Pengembangan, $3(3), 325-329$.

Zulkpli, Z., Abdullah, A. H., Kohar, U. H. A., \& Ibrahim, N. H. (2017). A Review Research On Infusion Approach In Teaching Thinking: Advantages And Impacts. Man In India, 97(12), 289-298. 